\title{
Developing Smart-Based Teaching And Learning Sets On Geometry At Senior High School In Central Java
}

\author{
Muchamad Subali Noto \\ Universitas Swadaya Gunung Djati \\ Cirebon, Indonesia \\ msubalinoto@fkip-unswagati.ac.id
}

Samsul Maarif

Universitas Muhammadyah Prof. Hamka

Jakarta, Indonesia

\author{
Yulyanti Harisman \\ STKIP PGRI Sumatera Barat, \\ Sumatera Barat, Indonesia
}

\author{
Asep Amam \\ Universitas Galuh \\ Ciamis, Indonesia
}

\begin{abstract}
The goal of this research was to produce SMART (Specific, Measurable, Achievable, Realistic, and Time-bound) based teaching and learning sets of geometry for grade VII, which should be valid and effective in its implementation. The process developing of teaching and learning sets in this research used the modification of Thiagarajan 4D model (became 3D), which were defined, design, and develop. The teaching and learning sets developed were a syllabus, teaching plan, and module. The field test was held at a senior high school in Jawa Tengah as the population of the research with eight parallel classes. Data were collected from validation and observation sheets, and from the test results of learning achievement. The results of the research were as follows (1) the teaching and learning sets were valid after revision based on feedbacks from experts and colleagues, and (2) the teaching and learning sets were effective because already fulfillthree indicators of effectiveness: student's achievement reached the classical accomplishment criteria 69.33, and individual accomplishment more than $75 \%$; the student's activeness influenced by $80.30 \%$ towards students' learning achievement; there was a difference of learning achievement between students of experiment class by the average 69.33 and students of conventional class by the average 61.60 .
\end{abstract}

Keywords - learning geometry, SMART based, teaching and learning sets.

\section{I.INTRODUCTION}

Mathematics learning has a vital role in developing students' reasoning competence and in arranging students' competences, especially geometrics, it can give students knowledge. However, the fact reveals that the students face some problems in learning geometric. One of the problems is they feel difficult in understanding some geometric figures. In addition, the monotonous method applied by the teacher also becomes a problem for the students.

The students' limited competency in geometry, such as understanding rectangular, causes unsatisfactory_result. Several classical instructional media like syllabus, lesson plan, and a module which are used by the teacher generally cannot stimulate the students' participation, skills, and achievement. Those phenomena are something to be pondered by teachers. Teachers should creatively design and develop both teaching-learning sets and learning method which can boost students' competences and motivate students to be more active, creative, and effective.

Based on the explanation above, it is essential to design some teaching and learning sets of geometry for grade VII which can increase students' ability and achievement. One of them is development of SMART (Specific, Measurable, Achievable, Realistic, and Time-bound) based teaching and learning sets of geometry for grade VII designed by using SMART indicators.

Designing teaching and learning sets means creating a syllabus, lesson plan, module which meet the criteria of SMART. It is by considering the congruity of curriculum and level of students' competencies (specific), the measurable indicators and specific material chosen (Measurable), the achievement of indicators (Achievable), the realistic and clear procedures to be implemented (Realistic), The effective and efficient time (Time bond). In this paper the writer assumes that the Instructional media of SMART based is important to be discussed.

Based on the explanation above, the research questions can be formulated as follows:

- What are the indicators of SMART (Specific, Measurable, Achievable, Realistic, and Time-bound) based teaching and learning sets of geometry that should be achieved?

- Are there any differences between the average of students' achievement who are taught using SMART based and the ones who are not taught using SMART based? 
- The followings are some important terms used in this study:

- Teaching and learning sets are a syllabus, teaching/lesson plan, and module.

- The development of teaching and learning sets uses 4D Thiagarajan model, Semmel and Semmel that now is modified as 3D Model, that is Define, Design, and Develop.

\section{II.METHODS}

The model of teaching and learning sets development used is a 4D model from Thiagarajan, Semmel, and Semmel [1] which consists of 4 steps. Those are Define, Design, Develop, and Disseminate. On the other hand, the procedures of a modified model, 3D, are limited up to develop step.

The procedures of development can be explained as follows:

\section{A. Defining}

This facet aims at determining and defining the requirements needed in learning by analyzing the objectives of learning and the limitation of materials. The activity in this step is the frontend analysis (curriculum analysis), pupils analysis, materials analysis, tasks analysis, and learning objective specification.

\section{B. Designing}

The following step purposes to designing teaching and learning sets in order to have the example of teaching and learning sets. The activities in this phase are designing test criteria, choosing media, choosing the format and first plan after determining specific learning objective.

\section{Developing}

The objective of this phase is to produce a draft of instructional media which has been revised by some experts and the data got is the result of try out.

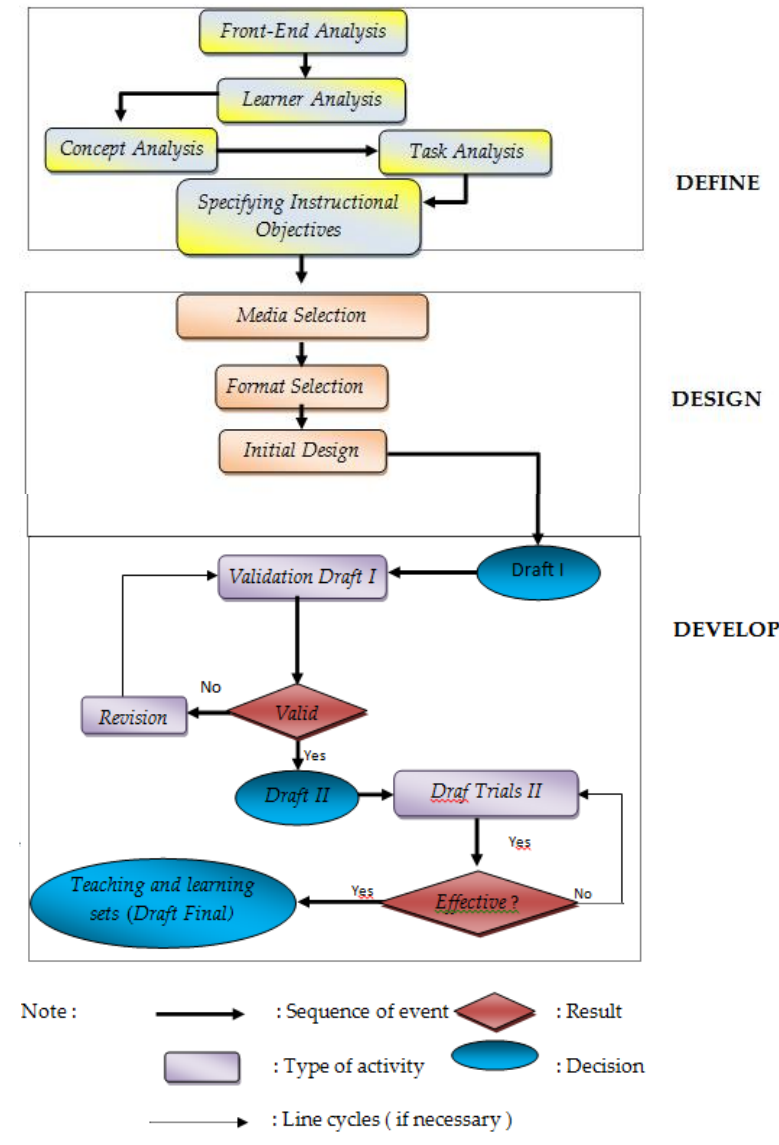

Fig. 1. Modification Model of Teaching and Learning Sets Development

\section{III.RESULTS AND DISCUSSION}

Based on SMART concept, the indicators that will be applied to the principles of developing teaching and learning sets and learning activities are:

The indicators in specific step are:

- $\quad$ Teaching and learning sets developed are in line with the strategies which are used,

- Teaching and learning sets developed are in line with the aims which will be reached,

- The aims that will be reached should be drawn using operational verbs,

- Teaching and learning sets developed contain some hints which are used to help to solve the problems of students.

The indicators in measurable step are:

- Teaching and learning sets developed contain some instruments which are used to measure the level of competences to be reached,

- The developed instruments are in line with the aims that will be reached, 
- The developed instruments contain a clear scoring in order to identify the student's competencies.

The indicators in achievable step are:

- Teaching and learning sets developed contain sources, tools, and materials that will be used to achieve aims/competences,

- $\quad$ Teaching and learning sets developed have obvious limitation and materials contents,

- Teaching and learning sets developed have distinct procedures in order to be easily applied.

The indicators in Realistic step are:

- Teaching and learning sets developed contain some instruments that can reach objectives of learning,

- Teaching and learning sets developed contain some factors that can be used to measure the requirements level of the students,

- Teaching and learning set developed to give some information about the essential points of materials.

The indicators in Realistic step are:

- Teaching and learning sets developed contain time limitation to achieve certain objectives.

- Teaching and learning set developed to contain the overall time limitation to achieve certain objectives.

The validators give scoring for all aspects of teaching and learning sets, such as syllabus, lesson/teaching plan, and module. Here is the table drew the result of scoring:

TABLE I. THE VALIDITY SCORING RESUlT FROM VALIDATORS

\begin{tabular}{|l|l|l|l|}
\hline No & \multicolumn{1}{|c|}{$\begin{array}{c}\text { Type of teaching and } \\
\text { learning sets }\end{array}$} & $\begin{array}{c}\text { The } \\
\text { Average of } \\
\text { validity } \\
\text { score }\end{array}$ & $\begin{array}{c}\text { Validity } \\
\text { Criterion }\end{array}$ \\
\hline 1 & Syllabus & 3.36 & valid \\
\hline 2 & Teaching/Lesson Plan & 3.24 & valid \\
\hline 3 & Module & 3.23 & valid \\
\hline Total of validity score & 9.83 & \\
\hline $\begin{array}{l}\text { The numbers of aspects } \\
\text { measurement }\end{array}$ & 3 & \\
\hline $\begin{array}{l}\text { The average of validity score of } \\
\text { teaching and learning sets }\end{array}$ & $9,83 / 3=3,28$ & valid \\
\hline
\end{tabular}

In this case, the validators mostly give a good score because most of the documents of learning are valid. They have been checked through the systemic procedures of instructional media development and fulfilled the requirements of how to design the documents.

The implementation of teaching and learning sets SMART based were applied to the eight grade students of High School in Jawa Tengah. The first one of fulfilling indicators of effectiveness in this research was that student's achievement reached the classical accomplishment criteria 69.33 more than KKM 65, and individual accomplishment more than 75\%. The second one was that the student's activeness influenced by
$80.30 \%$ towards students' learning achievement. The third one was that the average score of students who were taught using SMART based teaching and learning sets is better than the ones who did not teach using SMART based teaching and learning sets. To get the findings, it is vital to compare the average score of the students from the experimental and control/ conventional class by using comparative test.

Hypotheses:

$\mathrm{H}_{0}: \mu_{1}=\mu_{2}$ (There is no significant difference between the average score of students of the experimental and control class) $\mathrm{H}_{1}: \mu_{1} \neq \mu_{2}$ (There is significant difference between the average score of students from the experimental and control class)

After analyzing the data, it is shown that there is a significant difference between the average score of the students of the experimental and control class. The differences can be shown in the following table:

TABLE II. The AVERAgE SCORE OF TPB IN Class EXPERIMENT AND

\begin{tabular}{|c|l|c|c|c|c|}
\hline \multirow{2}{*}{ Class } & N & Mean & $\begin{array}{c}\text { Std. } \\
\text { Deviation }\end{array}$ & $\begin{array}{c}\text { Std. Error } \\
\text { Mean }\end{array}$ \\
\hline \multirow{2}{*}{ TPB } & Experiment & 30 & 70.33 & 6.671 & 1.218 \\
\cline { 2 - 7 } & Control & 30 & 60.60 & 6.339 & 1.157 \\
\hline
\end{tabular}

From the table above, it can be sum up that the average score of students in the experimental class (70.33) is higher than the average score of students in control class (60.60). It means that the average score of students in experimental class is better than the average score of students in control class.

\section{IV.CONCLUSION}

The designing of teaching and learning sets which includes a syllabus, teaching/lesson plan, and the module has catered the SMART characteristics. They are (1) The measurement of S reveals that in choosing the materials indicators is tuned to the level of students' competences; (2) The measurement of $\mathrm{M}$ reveals that the chosen indicators should be measurable; (3) The measurement of A shows that the students achievement can reach the standard score; (4) The measurement of $\mathrm{R}$ shows that the learning plan can be done effectively; (5) The measurement of $\mathrm{T}$ shows that the time boundary from task activity, teaching learning process, and evaluation activity accords the requirements. The implementation of SMART based teaching and learning sets reveals that the average score of students in experimental class is better than the average score of students in control class. On the other words, it is shown that using teaching and learning sets such as syllabus, lesson plan, and module by SMART based can increase the score of students' achievement.

\section{ACKNOWLEDGMENT}

Thanks to Mr. Budi Waluyo, Mrs. Roghibatul Luthfiyyah, provide feedback on this article and edited this paper. 


\section{REFERENCES}

[1] Trianto, Model Pembelajaran Terpadu dalam Teori dan Praktek (Jakarta: Prestasi Pustaka Publisher) (2007)

[2] Boise State University, Performance management-Creating SMART Objectives: Participant Guide 1-10 (2007)

[3] Depdiknas, Teknik Penyusunan Modul, (Jakarta: Departemen Pendidikan Nasional) pp. 1-12 (2008)

[4] Gafur A, Disain Instruksional (Solo: Tiga Serangkai) (1989)

[5] Iverson A, Preparing Program Objectives Theory \& Practice (Toronto. Ontario: The International Development Research Centre) (2003)

[6] Thiagarajan S., Semmel D.S. \& Semmel, M.I., Instructional Development for Training Teachers of Exceptional Children (Indiana: Indiana University Bloomington) (1974) 